\title{
Paenibacillus glacialis sp. nov., isolated from the Kafni glacier of the Himalayas, India
}

\author{
K. Hara Kishore, Zareena Begum, Akbar Ali Khan Pathan and S. Shivaji \\ Centre for Cellular and Molecular Biology, Uppal Road, Hyderabad 500 007, India
}

Correspondence

S. Shivaji

shivas@ccmb.res.in
Ash et al. (1993), based on phylogenetic analysis of the $16 \mathrm{~S}$ rRNA gene sequences of species known at the time, delineated the genus Bacillus into five phyletic lines (Groups 1 to 5) and this was in accordance with the earlier findings of Ash et al. (1991). Of particular interest was the observation that Bacillus polymyxa and its relatives belonging to Group 3 formed a coherent cluster compared with the other four Bacillus groups and possessed 'signature' bases unique to this group and a 22-base oligonucleotide specific to this group (Ash et al., 1993). It was apparent that these Group 3 bacilli were phylogenetically distinct from the remaining four groups of the genus Bacillus and they were thus assigned to the genus Paenibacillus. The genus comprises species that are facultatively anaerobic or strictly aerobic, rod-shaped, motile and produce ellipsoidal endospores. The diamino acid in the peptidoglycan is meso-diaminopimelic acid and unsaturated MK-7 is the menaquinone. The $\mathrm{G}+\mathrm{C}$ content of the DNA is 40 $54 \mathrm{~mol} \%$. At the time of writing, 102 species of the genus and two subspecies have been described and all the species are either mesophilic (Enright et al., 2003; Lim et al., 2006; Saha et al., 2005) or thermophilic (Chung et al., 2000) except Paenibacillus macquariensis (Marshall \& Ohye, 1966), which is psychrophilic. In this study, we describe a novel species of the genus Paenibacillus isolated from a soil sample from the Kafni glacier of the Himalayas, India.

The GenBank/EMBL/DDBJ accession numbers for the $16 \mathrm{~S}$ rRNA gene sequences and $r p o B$ gene sequence of strain $\mathrm{KFC9}^{\top}$ are EU815294EU815302 and G0871757, respectively.

Southern blot analysis, DNA-DNA relatedness data and phylogenetic trees based on $16 \mathrm{~S}$ rRNA gene and rpoB gene sequences are available with the online version of this paper.
Strain $\mathrm{KFC}^{\mathrm{T}}{ }^{\mathrm{T}}$ was isolated from a soil sample collected close to the Kafni glacier, at an altitude of $3500 \mathrm{~m}$, located at $30^{\circ} 13^{\prime} 5^{\prime \prime} \mathrm{N} 80^{\circ} 3^{\prime} 20^{\prime \prime} \mathrm{E}$ in the Himalayan mountain ranges in India. Approximately $0.1 \mathrm{~g}$ soil sample was suspended in $1 \mathrm{ml}$ sterile water, vortexed and plated on Luria-Bertani (LB) agar plates (Shivaji et al., 2005). The bacterial count was $1 \times 10^{6}$ c.f.u. per gram soil. One of the colonies, $\mathrm{KFC}^{\mathrm{T}}{ }^{\mathrm{T}}$, which was cream-coloured on tryptone soya agar [TSA (HiMEDIA M290), containing $\left(1^{-1}\right)$ pancreatic digest of casein, $15 \mathrm{~g}$; pancreatic digest of soybean meal, $5 \mathrm{~g}$; agar, $15 \mathrm{~g}$; $\mathrm{pH}$ 7.3] was studied in detail. Morphology was studied using light microscopy, scanning electron microscopy (SEM) and transmission electron microscopy (TEM) as described previously (Reddy et al., 2008 ) and the motility was assessed on $0.4 \%$ nutrient agar plates. Growth and biochemical characteristics (Lányí, 1987; Smibert \& Krieg, 1994), carbon assimilation and the sensitivity of the cultures to different antibiotics were determined by previously described methods (Reddy et al., 2004). Biochemical characteristics were performed using the Hi25 Enterobacteriaceae identification kit (KB003) and HiCarbohydrate kit parts A, B and C (KB009, HiMedia) according to the manufacturer's protocol. Paenibacillus antarcticus LMG $22078^{\mathrm{T}}$ and P. macquariensis LMG $6935^{\mathrm{T}}$ were used as reference strains for the study.

Cellular fatty acids were determined as described previously (Reddy et al., 2008) using cells of KFC91 ${ }^{\mathrm{T}}$ grown on TSA medium for 4 days at $22{ }^{\circ} \mathrm{C}$. Fatty acids were analysed by using the Sherlock Microbial Identification System (MIDI), according to the protocol described by Agilent

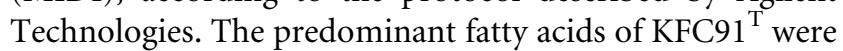
anteiso- $\mathrm{C}_{15: 0}(56.8 \%)$, iso- $\mathrm{C}_{15: 0}(9.9 \%)$ and $\mathrm{C}_{16: 1} \omega 11 \mathrm{c}$ 
$(6.0 \%)$. These fatty acids are typical of the genus Paenibacillus.

Menaquinones and polar lipids were determined in freezedried cells. Menaquinones were extracted as described by Collins et al. (1977) and were analysed by HPLC (Groth et al., 1997). DNA was isolated according to the procedure of Marmur (1961) and G+C content (mol\%) was determined from the melting point $\left(T_{\mathrm{m}}\right)$ curves (Sly et al., 1986) obtained by using a Lambda 2 UV-Vis spectrophotometer (Perkin Elmer) equipped with the Templab 2.0 software package (Perkin Elmer). Cell walls were prepared (Komagata \& Suzuki, 1987) from $500 \mathrm{mg}$ bacterial cell pellet and amino acids and peptides in the acid hydrolysates were analysed by two-dimensional TLC on cellulose plates (Schleifer \& Kandler, 1972).

Direct sequencing of the $16 \mathrm{~S}$ rRNA gene of strain $\mathrm{KFC} 91^{\mathrm{T}}$, performed as described previously (Reddy et al., 2000, 2008), gave ambiguous results, suggesting multiple copies of the rRNA gene. Presence of multiple copies of the $16 \mathrm{~S}$ rRNA gene is a characteristic feature of the genus Paenibacillus (Bosshard et al., 2002; Hamasaki et al., 2005; Nubel et al., 1996). Therefore, to overcome this problem, the 16S rRNA gene of $\mathrm{KFC} 91^{\mathrm{T}}$ was amplified with primers 16S1 (5'-AGAGTTTGATCCTGGCTCAG-3') and 16S2 (5'-AAGGAGGTGATCCAGCCGCA-3') corresponding to positions 8 to 28 and 1542 to 1522, respectively, of the Escherichia coli $16 \mathrm{~S}$ rRNA gene. The PCR product was then purified using a Quiaquick PCR purification kit (Qiagen), ligated into the pGEM-T plasmid vector (Kiran et al., 2005; Prabagaran et al., 2007) according to the manufacturer's protocol (Promega) and cloned in E. coli DH5 $\alpha$ cells. Transformants were selected on LB plates containing $100 \mu \mathrm{g}$ ampicillin $\mathrm{ml}^{-1}, 100 \mathrm{mM}$ IPTG and $50 \mathrm{mg} \mathrm{X}-\mathrm{Gal} \mathrm{ml}{ }^{-1}$. A total of nine transformants were sequenced.

The copy number of the 16S rRNA gene was determined by Southern blotting using ${ }^{32} \mathrm{P}$-labelled $16 \mathrm{~S}$ rRNA as a probe to hybridize the genomic DNA of strain $\mathrm{KFC}{ }^{\mathrm{T}}$ digested with BamHI, PstI or both BamHI/PstI (restriction sites for both BamHI and PstI are absent in the KFC91 ${ }^{\mathrm{T}} 16 \mathrm{~S}$ rRNA gene) as described by Sambrook et al. (1989). Genomic DNA was purified according to the protocol of Marmur (1961). Results indicated that KFC91 ${ }^{\mathrm{T}}$ contains multiple rRNA operons (Supplementary Fig. S1 available in IJSEM
Online), which is in agreement with the cloning experiment, where nine different sequences were found with a sequence difference of 0.1 to $0.9 \%$. In bacteria, the number of rRNA operons present varies in number from one to 15 (Klappenbach et al., 2001). At least eight 16S rRNA gene operons were found in Paenibacillus macerans (Hamasaki et al., 2005) and heterogeneity in the sequence among the multiple 16S rRNA operons may range from 0 to $5 \%$ (Bricker, 2000; Cilia et al., 1996; Mylvaganam \& Dennis, 1992; Ninet et al., 1996; Nubel et al., 1996; Pettersson et al., 1998). In Paenibacillus polymyxa, pairwise comparison of six sequences showed a difference of $2.5 \%$ in $12 \mathrm{rRNA}$ operons (Nubel et al., 1996). In another strain, Paenibacillus turicensis, six to eight different rRNA operons have been reported with seven different sequences with a sequence difference of 0.15 to $0.77 \%$ (Bosshard et al., 2002).

Pairwise alignment of the KFC91 ${ }^{\mathrm{T}} 16 \mathrm{~S}$ rRNA gene sequence (clone EU815300) performed using the ExPASy bioinformatics tool (http://www.expasy.org) showed similarities of 98.9, 98.7 and $93.2 \%$ with $P$. antarcticus LMG $22078^{\mathrm{T}}$ (AJ605292), P. macquariensis LMG $6935^{\mathrm{T}}$ (X60625) and Paenibacillus nematophilus DSM $13559^{\mathrm{T}} \quad(\mathrm{AF} 480935)$, respectively. To determine the phylogenetic affiliation of $\mathrm{KFC}^{\mathrm{T}}{ }^{\mathrm{T}}$, the $16 \mathrm{~S}$ rRNA gene sequence of the strain was aligned with all species of the genus Paenibacillus using CLUSTAL W (Thompson et al., 1997) and phylogenetic analysis was carried out as described previously (Bhadra et al., 2008). Phylogenetic trees were reconstructed using three tree-making algorithms, namely the maximumlikelihood method according to Guindon \& Gascuel (2003) and the neighbour-joining and maximum-parsimony methods according to Kimura's two-parameter model (Kimura, 1980) using MEGA3.1 (Kumar et al., 2004). Bootstrap analysis, based on 1000 replicate datasets, was performed to assess stability among the clades recovered in the phylogenetic tree. Phylogenetic analyses based on the above three methods, with the closely related species, indicated that strain $\mathrm{KFC} 91^{\mathrm{T}}$ clustered with $P$. antarcticus and P. macquariensis (Fig. 1). All cloned sequences of strain $\mathrm{KFC}^{\mathrm{T}}{ }^{\mathrm{T}}$ clustered with $P$. antarcticus and P. macquariensis (Supplementary Figs S2-S4).

In the DNA-DNA relatedness study performed according to Reddy et al. (2000), strain KFC91 ${ }^{\mathrm{T}}$ showed 39 and $52 \%$

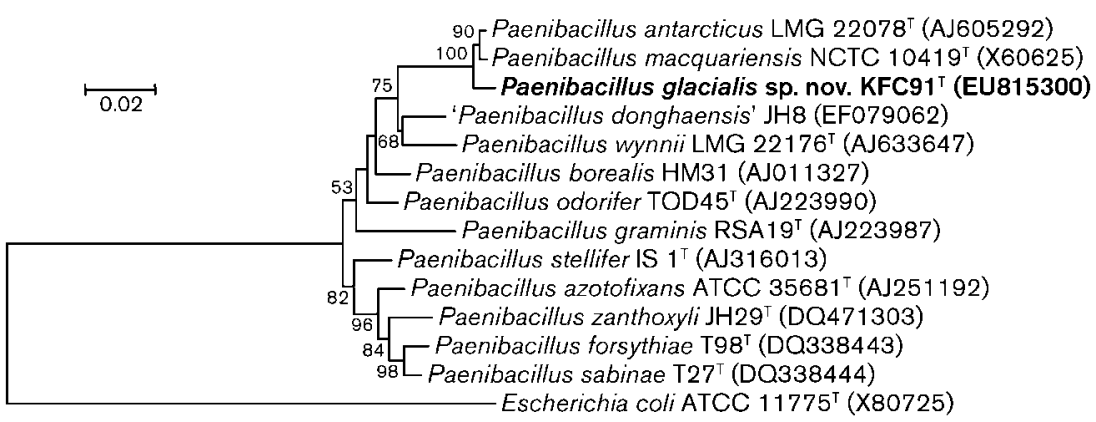

90. Paenibacillus antarcticus LMG 22078 (AJ605292)

LPaenibacillus glacialis sp. nov. KFC91 ${ }^{\top}$ (EU815300)

'Paenibacillus donghaensis' JH8 (EF079062)

- Paenibacillus wynni LMG 22176 (AJ633647)

- Paenibacillus borealis HM31 (AJ011327)

- Paenibacillus graminis RSA19 ${ }^{\top}$ (AJ223987)

Paenibacillus azotofixans ATCC 35681 ${ }^{\top}$ (AJ251192)

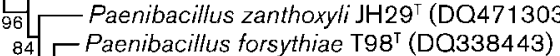

Escherichia coli ATCC $11775^{\top}$ (X80725)
Fig. 1. Neighbour-joining phylogenetic tree based on 16S rRNA gene sequences showing the phylogenetic relationship between strain $\mathrm{KFC}^{\top}{ }^{\mathrm{T}}$ and related species of the genus Paenibacillus. Escherichia coli ATCC $11775^{\top}$ (X80725) was used as an outgroup. Bootstrap values (expressed as percentages of 1000 replications) $>50 \%$ are given at branch nodes. Bar, 2 substitutions per 100 nucleotides. 
Table 1. Distinguishing characteristics of strain $\mathrm{KFC}^{\top}{ }^{\top}$, Paenibacillus antarcticus and Paenibacillus macquariensis

Strains: 1, Paenibacillus glacialis sp. nov. $\mathrm{KFC}^{\mathrm{T}}$; 2, Paenibacillus antarcticus $\mathrm{LMG} 22078^{\mathrm{T}}$; 3, Paenibacillus macquariensis LMG $6935^{\mathrm{T}}$. All data from this study. For fatty acid analysis, strains were cultured in TSA at $22{ }^{\circ} \mathrm{C}$. All isolates of strain $\mathrm{KFC} 91^{\mathrm{T}}$ were motile and positive for aesculin hydrolysis and acid production from maltose and D-glucose, but could not tolerate $5 \% \mathrm{NaCl}$ and were negative for $\mathrm{H}_{2} \mathrm{~S}$ production, gelatin liquefaction and acid production from glycerol, sorbitol, inulin and xylitol. +, Positive; -, negative; ND, not detected.

\begin{tabular}{|c|c|c|c|}
\hline Characteristics & 1 & 2 & 3 \\
\hline Habitat & Soil & Sediment & Soil \\
\hline Growth range $\left({ }^{\circ} \mathrm{C}\right)$ & $4-30$ & 4-31 & $0-25$ \\
\hline Oxidase & + & + & - \\
\hline Voges-Proskauer test & - & - & - \\
\hline Nitrate reduction & + & - & - \\
\hline Arginine dihydrolase & + & - & - \\
\hline Casein hydrolysis & + & - & - \\
\hline Starch hydrolysis & - & + & + \\
\hline Urease & - & + & - \\
\hline \multicolumn{4}{|l|}{ Acid production from: } \\
\hline L-Arabinose & - & + & + \\
\hline D-Xylose & - & + & + \\
\hline$N$-Acetylglucosamine & - & + & + \\
\hline Lactose & - & + & + \\
\hline D-Mannose & - & + & + \\
\hline Mannitol & - & - & + \\
\hline Melezitose & - & - & + \\
\hline Methyl $\alpha$-D-glucoside & - & + & + \\
\hline Sodium gluconate & - & - & + \\
\hline Galactose & - & + & + \\
\hline Sucrose & - & + & + \\
\hline Methyl $\alpha$-D-mannoside & - & - & + \\
\hline \multicolumn{4}{|l|}{ Fatty acids } \\
\hline $\mathrm{C}_{10: 0}$ & 1.1 & 0.7 & $\mathrm{ND}$ \\
\hline $\mathrm{C}_{12: 0}$ & 0.5 & 0.5 & 0.5 \\
\hline anteiso- $\mathrm{C}_{13: 0}$ & 0.5 & 0.5 & 0.5 \\
\hline iso- $\mathrm{C}_{14: 0}$ & 5.0 & 6.0 & 1.9 \\
\hline $\mathrm{C}_{14: 0}$ & 1.7 & 1.0 & 1.3 \\
\hline iso- $\mathrm{C}_{15: 0}$ & 9.9 & 7.7 & 7.5 \\
\hline anteiso- $\mathrm{C}_{15: 0}$ & 56.8 & 65.3 & 55.3 \\
\hline $\mathrm{C}_{16: 1} \omega 7 c$ alcohol & 4.0 & 5.0 & 0.9 \\
\hline iso- $\mathrm{C}_{16: 0}$ & 2.1 & 2.0 & 6.9 \\
\hline $\mathrm{C}_{16: 1} \omega 11 c$ & 6.0 & 5.1 & 2.1 \\
\hline $\mathrm{C}_{16: 0}$ & 2.7 & 1.2 & 7.8 \\
\hline iso- $\mathrm{C}_{17: 0}$ & 0.9 & 0.5 & 2.1 \\
\hline anteiso- $\mathrm{C}_{17: 0}$ & 1.5 & 1.0 & 3.9 \\
\hline iso- $\mathrm{C}_{17: 1} \omega 10 c$ & 0.7 & 0.5 & 0.5 \\
\hline $\mathrm{C}_{17: 1} \omega 9 c$ & 0.6 & 0.6 & $\mathrm{ND}$ \\
\hline iso- $\mathrm{C}_{18: 0}$ & ND & ND & 0.7 \\
\hline Polar lipids ${ }^{*}$ & PE, PG, DPG & PE, PG, DPG & PE, PG, DPG \\
\hline DNA G $+C$ content $(\mathrm{mol} \%)$ & 42.0 & 40.7 & 39 \\
\hline
\end{tabular}

${ }^{\star}$ PE, phosphatidylethanolamine; PG, phosphatidylglycerol; DPG, diphosphatidylglycerol. 
DNA-DNA relatedness with $P$. antarcticus LMG $22078^{\mathrm{T}}$ and P. macquariensis LMG $6935^{\mathrm{T}}$, respectively. Reverse DNA-DNA hybridizations also yielded similar results (Supplementary Table S1). In addition, when the $r p o B$ gene encoding the $\beta$ subunit of RNA polymerase of strain $\mathrm{KFC}^{\mathrm{T}}{ }^{\mathrm{T}}$ was amplified using primers $r p o B 1698 \mathrm{f}\left(5^{\prime}\right.$-AACATCGGTTTGATCAAC-3'; corresponding to E. coli position $1643)$ and rpoB2041r ( $5^{\prime}$-CGTTGCATGTTGGTACCCAT- ${ }^{\prime}$; corresponding to E. coli position 2041) (Dahllöf et al., 2000) and sequenced it showed 87.0 and $65.0 \%$ similarity with $P$. antarcticus LMG $22078^{\mathrm{T}}$ and P. macquariensis LMG $6935^{\mathrm{T}}$, respectively. Phylogenetic analyses of the $r p o B$ gene sequence based on a neighbour-joining tree with the closely related

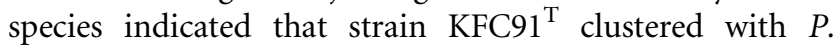
antarcticus with a sequence similarity of $87.0 \%$ (Supplementary Fig S5). Considering 97.7\% sequence similarity of the $r p o B$ gene as a cut-off for species delineation correlated with $<70 \%$ DNA-DNA relatedness (Adekambi et al., 2008), and based on differences observed in the phenotypic characteristics and chemotaxonomic properties (Table 1), strain $\mathrm{KFC} 91^{\mathrm{T}}$ is regarded as a new species of the genus Paenibacillus, for which the name Paenibacillus

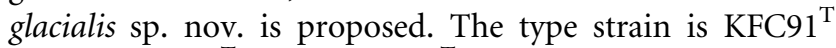
$\left(\right.$ NCCB $100252^{\mathrm{T}}=$ DSM $\left.22343^{\mathrm{T}}\right)$.

\section{Description of Paenibacillus glacialis sp. nov.}

Paenibacillus glacialis (gla.cia'lis. L. fem. adj. glacialis icy, referring to the cold, icy environment from which the strain was isolated).

Cells are Gram-positive, motile, aerobic and rod-shaped $(0.5 \mu \mathrm{m} \times 2.2 \mu \mathrm{m})$. Ellipsoidal endospores are visible in swollen sporangia in the subterminal region of the cell. Colonies grown on TSA are circular, convex with entire margins, cream-coloured and non-pigmented. Growth occurs between 4 and $30{ }^{\circ} \mathrm{C}$ and at pH 6-7.5. Optimum growth occurs at $22{ }^{\circ} \mathrm{C}$ and $\mathrm{pH}$ 7.0. Tolerates $2 \% \mathrm{NaCl}$ but not $5 \% \mathrm{NaCl}$. Positive for catalase but negative for lysine decarboxylase, ornithine decarboxylase, phenylalanine deamination, citrate utilization, indole production and the methyl red test. Cells utilize D-fructose, cellobiose, Dglucose, inositol, ribose, trehalose, maltose, erythritol, sucrose, inulin and salicin as the sole carbon source but do not utilize raffinose, adonitol, D-arabinose, dulcitol, Dxylose, D-mannose or glycerol. Acid is produced from Dfructose, trehalose, salicin and cellobiose. Acid is not produced from raffinose, melibiose, dulcitol, inositol, adonitol, D-rhamnose, D-arabinose or sorbose. The cellwall diamino acid is meso-diaminopimelic acid. The major fatty acids are anteiso- $\mathrm{C}_{15: 0}(56.8 \%)$, iso- $\mathrm{C}_{15: 0}(9.9 \%)$ and $\mathrm{C}_{16: 1} \omega 11 c(6.0 \%)$. The major menaquinone is MK-7. The DNA G + C content of the type strain is $42.0 \mathrm{~mol} \%$. The major cellular phospholipids are phosphatidylglycerol, diphosphatidylglycerol and phosphatidylethanolamine. Sensitive to $\left(\mu \mathrm{g} \mathrm{disc}^{-1}\right)$ kanamycin (30), novobiocin (30), lomefloxacin (30) and chloramphenicol (30) but resistant to streptomycin (10).
The type strain is $\mathrm{KFC}^{\mathrm{T}}{ }^{\mathrm{T}}\left(=\mathrm{NCCB} 100252^{\mathrm{T}}=\mathrm{DSM}\right.$ $22343^{\mathrm{T}}$ ), isolated from a soil sample from the Kafni glacier of the Himalayas, India.

\section{Acknowledgements}

We would like to thank the Department of Biotechnology, Government of India for financial support to S. S.

\section{References}

Adékambi, T., Shinnick, T. M., Raoult, D. \& Drancourt, M. (2008). Complete $r p o B$ gene sequencing as a suitable supplement to DNADNA hybridization for bacterial species and genus delineation. Int $J$ Syst Evol Microbiol 58, 1807-1814.

Ash, C., Farrow, J. A. E., Wallbanks, S. \& Collins, M. D. (1991). Phylogenetic heterogeneity of the genus Bacillus revealed by comparative analysis of small-subunit-ribosomal RNA sequences. Lett Appl Microbiol 13, 202-206.

Ash, C., Priest, F. G. \& Collins, M. D. (1993). Molecular identification of rRNA group 3 bacilli (Ash, Farrow, Wallbanks and Collins) using a PCR probe test. Proposal for the creation of a new genus Paenibacillus. Antonie van Leeuwenhoek 64, 253-260.

Bhadra, B., Raghukumar, C., Pindi, P. K. \& Shivaji, S. (2008). Brevibacterium oceani sp. nov., isolated from deep-sea sediment of the Chagos Trench, Indian Ocean. Int J Syst Evol Microbiol 58, 57-60.

Bosshard, P. P., Zbinden, R. \& Altwegg, M. (2002). Paenibacillus turicensis sp. nov., a novel bacterium harbouring heterogeneities between 16S rRNA genes. Int J Syst Evol Microbiol 52, 2241-2249.

Bricker, B. J. (2000). Characterization of the three ribosomal RNA operons $r r n A, r r n B$, and $r r n \mathrm{C}$, from Brucella melitensis. Gene 255, 117-126.

Chung, Y. R., Kim, C. H., Hwang, I. \& Chun, J. (2000). Paenibacillus koreensis sp. nov., a new species that produces an iturin-like antifungal compound. Int J Syst Evol Microbiol 50, 1495-1500.

Cilia, V., Lafay, B. \& Christen, R. (1996). Sequence heterogeneities among 16S ribosomal RNA sequences, and their effect on phylogenetic analyses at the species level. Mol Biol Evol 13, 451-461.

Collins, M. D., Pirouz, T., Goodfelow, M. \& Minkin, D. E. (1977). Distribution of menaquinones in actinomycetes and corynebacteria. J Gen Microbiol 100, 221-230.

Dahllöf, I., Baillie, H. \& Kjelleberg, S. (2000). rpoB-based microbial community analysis avoids limitations inherent in 16S rDNA gene intraspecies heterogeneity. Appl Environ Microbiol 66, 3376-3380.

Enright, M. R., Mclnerney, J. O. \& Griffin, C. T. (2003). Characterization of endospore-forming bacteria associated with entomopathogenic nematodes, Heterorhabditis spp., and description of Paenibacillus nematophilus sp. nov. Int J Syst Evol Microbiol 53, 435-441.

Groth, I., Schumann, P., Rainey, F. A., Martin, K., Schuetze, B. \& Augusten, K. (1997). Demetria terragena gen. nov., sp. nov., a new genus of actinomycetes isolated from compost soil. Int J Syst Bacteriol 47, 1129-1133.

Guindon, S. \& Gascuel, O. (2003). A simple, fast, and accurate algorithm to estimate large phylogenies by maximum likelihood. Syst Biol 52, 696-704.

Hamasaki, Y., Watanabe, Y., Kotoura, S., Fuchu, H., Sugiyama, M., Hashizume, K. \& Morita, H. (2005). Paenibacillus macerans possesses two types of $16 \mathrm{~S}$ rDNA copies in a genome with a length difference of twelve base pairs. Biosci Biotechnol Biochem 69, 1995-1998. 
Kimura, M. (1980). A simple method for estimating evolutionary rates of base substitutions through comparative studies of nucleotide sequences. J Mol Evol 16, 111-120.

Kiran, M. D., Annapoorni, S., Suzuki, I., Murata, N. \& Shivaji, S. (2005). Cis-trans isomerase gene in psychrophilic Pseudomonas syringae is constitutively expressed during growth and under conditions of temperature and solvent stress. Extremophiles 9, 117-125.

Klappenbach, J. A., Saxman, P. R., Cole, J. R. \& Schmidt, T. M. (2001). rrndb: the ribosomal RNA operon copy number database. Nucleic Acids Res 29, 181-184.

Komagata, K. \& Suzuki, K. (1987). Lipid and cell-wall analysis in bacterial systematics. Methods Microbiol 19, 161-207.

Kumar, S., Tamura, K. \& Nei, M. (2004). MEGA3: integrated software for molecular evolutionary genetics analysis and sequence alignment. Brief Bioinform 5, 150-163.

Lányí, B. (1987). Classical and rapid identification methods for medically important bacteria. Methods Microbiol 19, 1-67.

Lim, J.-M., Jeon, C. O., Lee, J.-C., Xu, L.-H., Jiang, C.-L. \& Kim, C.-J. (2006). Paenibacillus gansuensis sp. nov., isolated from desert soil of Gansu Province in China. Int J Syst Evol Microbiol 56, 2131-2134.

Marmur, J. (1961). A procedure for the isolation of deoxyribonucleic acid from microorganisms. J Mol Biol 3, 208-218.

Marshall, B. J. \& Ohye, D. F. (1966). Bacillus macquariensis n.sp., a psychrotrophic bacterium from sub-Antarctic soil. J Gen Microbiol 44, $41-46$.

Mylvaganam, S. \& Dennis, P. P. (1992). Sequence heterogeneity between the two genes encoding 16S rRNA from the halophilic archaebacterium Haloarcula marismortui. Genetics 130, 399-410.

Ninet, B., Monod, M., Emler, S., Pawlowski, J., Metral, C., Rohner, P., Auckenthaler, R. \& Hirschel, B. (1996). Two different $16 \mathrm{~S}$ rRNA genes in a mycobacterial strain. J Clin Microbiol 34, 2531-2536.

Nübel, U., Engelen, B., Felske, A., Snaidr, J., Wieshuber, A., Amann, R. I., Ludwig, W. \& Backhaus, H. (1996). Sequence heterogeneities of genes encoding 16S rRNAs in Paenibacillus polymyxa detected by temperature gradient gel electrophoresis. J Bacteriol 178, 5636-5643.

Pettersson, B., Bölske, G., Thiaucourt, F., Uhlén, M. \& Johansson, K. E. (1998). Molecular evolution of Mycoplasma capricolum subsp. capripneumoniae strains, based on polymorphisms in the 16S rRNA genes. J Bacteriol 180, 2350-2358.

Prabagaran, S. R., Manorama, R., Delille, D. \& Shivaji, S. (2007). Predominance of Roseobacter, Sulfitobacter, Glaciecola and
Psychrobacter in seawater collected off Ushuaia, Argentina, SubAntarctica. FEMS Microbiol Ecol 59, 342-355.

Reddy, G. S. N., Aggarwal, R. K., Matsumoto, G. I. \& Shivaji, S. (2000). Arthrobacter flavus sp. nov., a psychrophilic bacterium isolated from a pond in McMurdo Dry Valley, Antarctica. Int J Syst Evol Microbiol 50, 1553-1561.

Reddy, G. S. N., Matsumoto, G. I., Schumann, P., Stackebrandt, E. \& Shivaji, S. (2004). Psychrophilic pseudomonads from Antarctica: Pseudomonas antarctica sp. nov., Pseudomonas meridiana sp. nov. and Pseudomonas proteolytica sp. nov. Int J Syst Evol Microbiol 54, 713719.

Reddy, G. S. N., Prabagaran, S. R. \& Shivaji, S. (2008). Leifsonia pindariensis sp. nov., isolated from the Pindari glacier of the Indian Himalayas, and emended description of the genus Leifsonia. Int J Syst Evol Microbiol 58, 2229-2234.

Saha, P., Mondal, A. K., Mayilraj, S., Krishnamurthi, S., Bhattacharya, A. \& Chakrabarti, T. (2005). Paenibacillus assamensis sp. nov., a novel bacterium isolated from a warm spring in Assam, India. Int J Syst Evol Microbiol 55, 2577-2581.

Sambrook, J., Fritsch, E. F. \& Maniatis, T. (1989). Molecular Cloning: a Laboratory Manual, 2nd edn. Cold Spring Harbor, NY: Cold Spring Harbor Laboratory.

Schleifer, K. H. \& Kandler, O. (1972). Peptidoglycan types of bacterial cell walls and their taxonomic implications. Bacteriol Rev 36, 407477.

Shivaji, S., Chaturvedi, P., Reddy, G. S. N. \& Suresh, K. (2005). Pedobacter himalayensis sp. nov., from the Hamta glacier located in the Himalayan mountain ranges of India. Int J Syst Evol Microbiol 55, 1083-1088.

Sly, L. I., Blackall, L. L., Kraat, P. C., Tian-Shen, T. \& Sangkhobol, V. (1986). The use of second derivative plots for the determination of mol\% guanine plus cytosine of DNA by the thermal denaturation method. J Microbiol Methods 5, 139-156.

Smibert, R. M. \& Krieg, N. R. (1994). Phenotypic characterization. In Methods for General and Molecular Bacteriology, pp. 607-654. Edited by P. Gerhardt, R. G. E. Murray, W. A. Wood \& N. R. Krieg. Washington, DC: American Society for Microbiology.

Thompson, J. D., Gibson, T. J., Plewniak, F., Jeanmougin, F. \& Higgins, D. G. (1997). The CLUSTAL_X windows interface: flexible strategies for multiple sequence alignment aided by quality analysis tools. Nucleic Acids Res 25, 4876-4882. 